\title{
Pentecostal pacifist impulse and the violent God of the Hebrew Bible: A balancing act of hermeneutics
}

\author{
MARIUS NEL (NORTH-WEST UNIVERSITY)
}

\begin{abstract}
Most early Pentecostals took a pacifist stance toward violence and war, based on Jesus' example of love for the enemies, and relegated human violence promoted as God's will in the Hebrew Bible to a description of broken and sinful human behaviour that was not viewed as normative for Christian behaviour. Since the 1930s and 1940s, Pentecostals adopted Evangelicals' hermeneutic, and inter alia their Augustinian just war doctrine and support for nationalism and patriotism. It is argued that a new hermeneutic consensus that has been developing among Pentecostal scholars since the 1970s requires that pacifism should be placed on the Pentecostal agenda because it recognises that the Bible does not speak in a monosyllabic way; the Hebrew Bible contains conflicting views on violence that cannot be systematised into a clearly uniform "biblical view."
\end{abstract}

Keywords: Pentecostal movement, pacifism, violence, violent God

\section{A INTRODUCTION}

The majority of early twentieth-century Pentecostal denominations were peace churches that maintained a pacifist stance and encouraged their members to choose conscientious objection to military service. ${ }^{1}$ Thirteen of twenty-one or sixty-two per cent of American Pentecostal groups formed by 1917 showed evidence of being pacifist sometime in their history with a gradual shift away from pacifism to military support and chaplaincy. ${ }^{2}$ Jay Beaman $^{3}$ estimates that

* Submitted: 11/07/2018; peer-reviewed: 12/08/2018; accepted: 12/08/2018. Marius Nel, "Pentecostal pacifist impulse and the violent God of the Hebrew Bible: A balancing act of hermeneutics," 31 no. 2 (2018): 423-441. DOI: https://doi.org/10. 17159/2312-3621/2018/v31n2a9.

1 Jean-Daniel Pluess, "Pentecostalism in Europe and the Former Soviet Union," in The Cambridge Companion to Pentecostalism (ed. Cecil M. Robeck \& Amos Yong; Cambridge University Press, New York, 2014), 108-130.

2 Jay Beaman, Pentecostal Pacifism: The Origins, Development and Rejection of Pacifist Beliefs among the Pentecostals (Hillsboro: Center for Mennonite Brethren Studies, 1989), 117. The major organisation today for American Pentecostal Christians who believe in pacifism is the Pentecostal Charismatic Peace Fellowship (PCPF; https://pcpj.org).

Jay Beaman, "Pentecostal and holiness pacifism," Pentecostal pacifism 2009, 1-3. [cited 5 August 2017]. Online: http://www.Pentecostalpacifism.com/. 
in the United States, between five and ten per cent of all conscientious objectors in World War I were Pentecostals or Holiness men. This is all the more astounding since Pentecostalism as a movement was about ten years old, and quite small. Denominations such as the Church of God in Christ (a Mennonite church influenced by the Holiness movement ${ }^{4}$ and the Assemblies of God said "no" to Christian combatant participation in war. A 1917 statement by a Church of God in Missouri states unequivocally, "We are forever opposed to war ... we are opposed to our members training or in any way preparing to kill, we refuse to be trained or drilled for combatant military service in any nation, Heartily approved". 5 By the 1930s and 1940s, however, Pentecostals had adapted their pacifist stance. It is argued that it was due to the change in their hermeneutical perspective that they aligned to those of conservative Evangelicals.

The article concentrates on the question of how Pentecostals reconciled the representation of a violent God inciting God's people to violent acts in parts of the Hebrew Bible with their early pacifist and later non-pacifist stance? The article describes the representation of a violent God in the Hebrew Bible before comparing it with the discounting of this representation by early and later Pentecostals. The purpose is to compare the different hermeneutical viewpoints of Pentecostals in terms of an essential issue concerned with pacifism in order to demonstrate the influence of a changing hermeneutic on an ethical issue. ${ }^{6}$

\section{B THE OLD TESTAMENT AND VIOLENCE}

Raymund Schwager ${ }^{7}$ states that approximately a thousand passages in the Hebrew Bible describe God's anger about the sins of people in violent terms, with him threatening or applying punishment consisting of destruction and death. ${ }^{8}$ YHWH takes revenge and annihilates people like a sweeping fire. "No

4 Jay Beaman, "Introduction," in Pentecostal and Holiness Statements on War and Peace (ed. Jay Beaman \& Brian K. Pipkin; Eugene, Or: Pickwick, 2013), 43. (Pentecostals, peacemaking and social justice 6).

5 Peachey 2013:x.

6 The article commemorates Willie Wessels' contribution to Pentecostal hermeneutics, among many others. His influential article, "Skrifgebruik en samelewing: Die Apostoliese Geloofsending van Suid-Afrika", especially influenced the hermeneutical debate within South African Pentecostal circles.

7 Raymund Schwager, Must There be Scapegoats? Violence and Redemption in the Bible (transl by M.L. Assad; San Francisco: Harper \& Row, 1987), 60.

8 Gustavo Gutiérrez, The Truth Shall Make you Free: Confrontations (transl. by M. J. O' Connell; Maryknoll, NY: Orbis, 1990), 135; Mathew Shadle, "Theology and the Origins of Conflict: The Shining Path Insurgency in Peru, 1980-2000," Political Theology 14/3 (2013): 302. DOI: https://doi.org/10.1179/1462317X13Z.0000000. 
other topic is as often mentioned as God's bloody works". ${ }^{9}$ Another hundred passages state that YHWH explicitly commands people to kill others. ${ }^{10}$

There are two sides to the problem: What YHWH does as a violent actor, even if he is only threatening people, and what humans are commanded to do, and actually do in YHWH's name. Schwager ${ }^{11}$ concludes that religiously justified violence is an unavoidable and central theme of the Hebrew Bible. For instance,

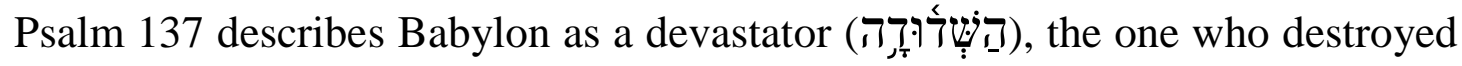
Jerusalem and the Temple and took Judah into exile, ${ }^{12}$ and then prays, "Happy shall they be who pay you back what you have done to us! Happy shall they be

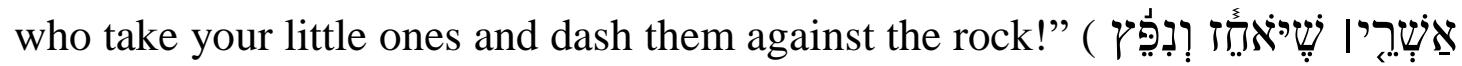

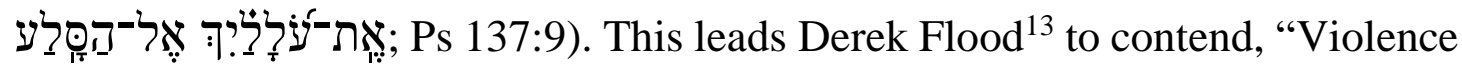
and bloodshed committed in God's name is a major theme of the Old Testament". Various forms of violence existed in the Hebrew Bible world, including interpersonal physical assault and murder, the death penalty, and, of course, war ${ }^{14}$ leading a "New Atheist" such as Richard Dawkins ${ }^{15}$ to assert that the God of the Hebrew Bible is arguably "the most unpleasant character in all of fiction: jealous and proud of it, a petty, unjust, unforgiving control-freak; a vindictive, blood-thirsty ethnic cleanser; a misogynistic, homophobic, racist, infanticidal, genocidal, filicidal, pestilential, megalomaniacal, sadomasochistic, capriciously malevolent bully".

Parts of the Hebrew Bible ascribe genocide, cannibalism, infanticide and rape to God. ${ }^{16}$ Consider Jeremiah 13:22-27 who answers the question, "Why have these things come upon me?", and YHWH answering that Israel's iniquities caused their humiliation. "I will scatter you like chaff driven by the wind from

\footnotetext{
9 Daniel G. Reid and Tremper Longman, "When God Declares War: The Violence of God Can Only be Understood in the Shadow of the Cross," Christianity Today (October 28, 1996): 17.

10 Schwager, Must There be Scapegoats, 60.

11 Schwager, Must there be Scapegoats, 61.

12 Karen Armstrong, Fields of Blood: Religion and the History of Violence (London: The Bodley Head, 2014), 37.

13 Derek Flood, Disarming Scripture: Cherry-Picking Liberals, Violence-Loving Conservatives, And Why we All Need to Learn to Read the Bible Like Jesus Did (San Francisco: Metanoia, 2014), 11.

14 Eben Scheffler, "War and Violence in the Old Testament World: Various Views," in Animosity, the Bible, and us (ed. John T. Fitzgerald, Fika J. Van Rensburg and Herrie F. Van Rooy; Atlanta: SBL, 2009), 1-17. (SBL Global; Perspectives on Biblical Scholarship 12).

15 Richard Dawkins, The God Delusion (New York: Houghton Mifflin Harcourt, 2006), 51.

16 Simon Vestdijk, De toekomst der religie (Arnhem: Van Loghum Slaterus, 1952), 12.
} 


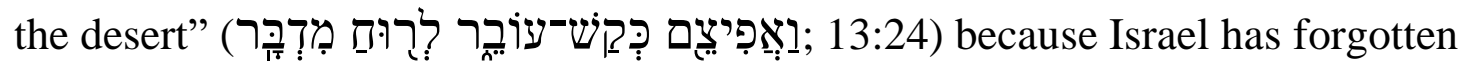
her God. "I myself will lift up your skirts over your face, and your shame will be

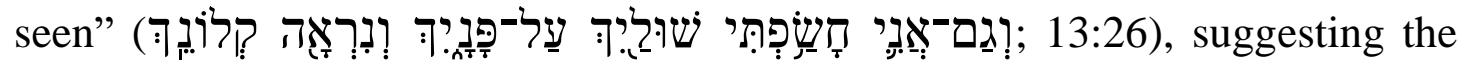
brutal rape of Israel because of their abominations, adulteries, neighing, and

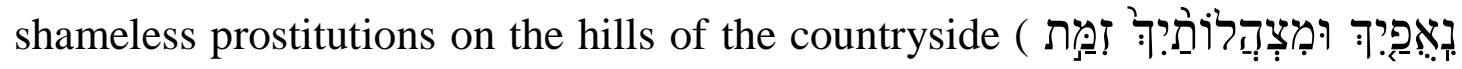

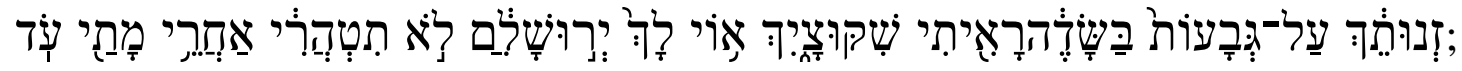
13:27). The prophets do not only use metaphorical language in describing the punishment of those who reject their God because Israel's history includes the terrible and humiliating suffering in response to her disobedience and idolatry, as in the Assyrian and Babylonian exile experiences, because her God was a jealous God (Exod 20:5).

When the people of Israel entered the Promised Land, they were commanded by their God to commit mass genocide on the indigenous inhabitants of the country, described in terms of a holy war or crusade. They should devour all the people in the land and show them no pity because they were a people holy to YHWH their God (Deut 7:5-16), separated from the other nations to live exclusively in faithfulness to YHWH (Deut 4:24). "This is a directive for so-called 'holy war,' a conflict led by the Lord against hostile and irredeemable foes who have an implacable resistance to God and His people". ${ }^{17}$ Out of love for his chosen people, God demands absolute obedience, partly inciting violence against other people and partly threatening violence to the Israelites themselves if they break the covenant. This line of thought determines deuteronomistic historiography, with defection from YHWH being severely punished and obedience being rewarded with victory over and the annihilation of the enemies along with the blessings of prosperity and good health (Deut 27:9-30:20), linking Israel's God in many places in the Hebrew Bible to violence. ${ }^{18}$ The theologising of the difference between "us" and "the others" is the real and actual problem, explains Jan Assmann, ${ }^{19}$ for God is thereby made the guarantor of who are on the right side, and who are therefore his (and "our") enemies. ${ }^{20}$ Its theology creates an ideology of nationalism and patriotism.

17 Ted Cabal et al, The Apologetics Study Bible: Real Questions, Straight Answers, Stronger Faith (Nashville: Holman Bible Publishers, 2007), 278.

18 Nielsen, K., "The violent God of the Old Testament: Reading strategies and responsibilities," in Encountering violence in the Bible (eds. M. Zehnder \& H. Hagelia; Sheffield Phoenix, Sheffield, 2013), 209.

19 Jan Assmann, Die Mosaische Unterscheidung oder der Preis des Monotheismus (München: Hanser, 2013), 31 (Edition Akzen).

20 The result is that our "objective" accounts of "our" history can conceal effectively the voice of "the other" so that we can justify our own position at all times, writes Stanley Hauerwas, After Christendom: How the Church is to behave iffreedom, Justice, and a Christian Nation are Bad Ideas (Nashville: Abingdon, 1991), 137. 
The genocide of the indigenous population is justified as necessary to prevent Israel from being infected by the degenerate religion of the Canaanites, a theme that recurs again and again. ${ }^{21}$ Pure faith and worship in Israel could only occur when they coincided with the complete elimination and annihilation of the Canaanites. ${ }^{22}$ Ethnic cleansing is the way to ensure cultic purity, a precautionary measure against false worship. ${ }^{23}$

The concept of the ban (Hebrew herem) is firmly embedded in a cultic context, connected to admonitions to abstain from non-Yahwistic cults and to destroy their objects (Deut 13), implying that the main goal in the expulsion and possible extermination of the Canaanites is the destruction of their cults and the protection of Israelite identity and liberty. ${ }^{24}$ The ban can also be applied to apostate Israelites, as Deuteronomy 13 explains, showing that the motivation for the ban does not lie in ethnic otherness per se.

Friedrich Schwally ${ }^{25}$ introduced the term "holy war" into biblical scholarship. "Israel" means "El is battling" and YHWH was viewed as the warrior El, after whom Israel was named. Schwally associated warfare in Israel with the notion of YHWH as a covenant God who defends the federation. In covenant theology, YHWH was worshipped as a warrior; corporate worship was the context in which war was conducted and which made it a holy war. War could be regarded as a kind of sacrificial service and as worship. ${ }^{27}$ Gerhard Von $\operatorname{Rad}^{28}$ responds to Schwally by developing a theory of holy war based on the embedding of war in rituals that made it a cultic performance, the decisive intervention of YHWH in the human conflicts and the defensive role of the Israelites in these conflicts. The view became universally accepted among Old Testament scholars during the latter half of the previous century. ${ }^{29}$

21 Ron J. Sider and R. K. Taylor, "Jesus and Violence: Some Critical Objections", in Readings in Christian Ethics (ed. David K. Clarke and Robert V. Rakestraw, vol. 2: Issues and application; Grand Rapids: BakerAcademic, 1996), 511.

22 John F. Walvoord and Roy B. Zuck, The Bible Knowledge Commentary: Old Testament (Colorado Springs: David C. Cook, 1984), 342.

23 John J. Collins, Does the Bible Justify Violence? (Minneapolis: Fortress, 2004), 9.

24 Zehnder, "The Annihilation of the Canaanites," 289.

25 Friedrich Schwally, Der Heilige Krieg im Alten Israel (Leipzig: Dieterich'sche Verlagsbuchhandlung, 1910).

26 Millard C. Lind, Yahweh is a Warrior (Scottdale, Pa: Herald, 1980), 104-105.

27 Stanley Hauerwas, "Sacrificing the Sacrifices of War" Criswell Theological Review 4.2 (2007): 80.

28 Gerhard Von Rad, Der Heilige Krieg im Alten Israel (Göttingen: Vandenhoeck \& Ruprecht, 1951), 39-40.

29 Scheffler, "War and Violence in the Old Testament World", 3. 
Crouch $^{30}$ argues that the interaction between history, society and ideology provides the essential source material for ethical thought and is fundamental to understanding what warfare was all about. It should be kept in mind that the biblical texts are not historically reliable accounts of early Israelite history but ideological fictions from a much later time. ${ }^{31}$ The texts are not naïve reflections of primitive practice but programmatic ideological statements from the late seventh century B.C.E. or later. They cannot be accepted as presenting what happened but rather what a later interpreter wanted to demonstrate by using the information to address a new situation. These war texts present expansionist policies of King Josiah or fantasies of powerless Judeans after the exile, argues Collins. In whatever way, they were used to construct the identity of "Israel"; what they reflect is not Israel as such but Israel as the authors thought it should ideally be. Israel's identity is defined negatively by a sharp differentiation from the surrounding peoples, and positively by the prescriptions of a covenant with a jealous God. ${ }^{32}$ Lori Rowlett ${ }^{33}$ makes the provocative statement that neither Deuteronomy nor Joshua was intended originally in the historical context of their composition to incite literal violence against ethnic outsiders, but both books were rather directed at insiders who pose a threat to the hierarchy that is being asserted. I think this is a contentious statement that defends the biblical books in an unjustified manner. Perhaps Carolyn Sharp ${ }^{34}$ is more justified in acknowledging that the book of Joshua remains difficult for contemporary readers committed to the promotion of peace and reconciliation, but it has value as a resource for the feminist or postcolonial-minded interpreter. It contains insistent rhetoric of genocide concerning the "other" and the justification of "us", but the book of Joshua also acknowledges the subjectivity of those whom it is ostensibly concerned to exterminate.

Although parts of the Hebrew Bible show a positive attitude to war, there are also other voices. With the prophetic movement a situation was established in ancient Israel where the king did not have the only or final say about such matters, representing other voices of criticism (which were not always appreciated). Critical thinking about war and Israel's participation in war against the super powers started to develop. Examples can be found in 1 Kings 22 where Micaiah ben Imlah warned King Ahab of Israel, contrary to the advice of four hundred court prophets who prophesied victory for the Israelite king: "I saw all

30 Crouch, "War and Violence in the Old Testament World", 5-11.

31 John J. Collins, "The Zeal of Phinehas: The Bible and the Legitimation of Violence," Journal of Biblical Literature 122.1 (2003): 14.

32 Collins, "The Zeal of Phinehas", 15.

33 Joshua and the Rhetoric of Violence: A New Historical Analysis (Sheffield: Sheffield Academic Press, 1996), 12-13

34 "'Are You for Us, Or for our Adversaries?' A Feminist and Postcolonial Interrogation of Joshua 2-12 for the Contemporary Church," Interpretation: A Journal of Bible and Theology 66.2 (2012): 152. 
Israel scattered on the mountains, like sheep that have no shepherd; and the LORD said, "These have no master; let each one go home in peace"' (1 Kgs 22:17; NRSV). Ahab responded to the prophet with his unwelcome message by throwing him in prison, and Ahab died on the battlefield as a fulfilment of the prophecy about the shepherd's death. Another example is Isaiah's advice as expressed in Isaiah 2:2-4; 30:15-17. That Ahaz did follow Isaiah's advice and did not engage in the Syro-Ephraimitic war, offered the desired tribute to Assyria and called for help meant that the southern kingdom lasted a hundred years longer than the north. ${ }^{35}$ Jeremiah also criticised King Zedekiah's war effort against the Babylonians toward the end of the sixth century B.C.E. His criticism differed from Isaiah's. According to Jeremiah, speaking to his king who was involved in a defensive war that was usually justified, Nebuchadnezzar's onslaught on Jerusalem should be interpreted as a chastisement for the injustices that prevailed within Jerusalem, as described in 2 Kings 23:27; 24:3, 20; Jer 4:3, $6 ; 21: 5 ; 34: 22$. YHWH sided with the enemy; to participate in war against the enemy was equivalent to fighting against YHWH. Jeremiah opened a new perspective on war. "Whether to go to war or not should not be seen in isolation: the people cannot practise social injustice and idolatry among themselves and then expect Yahweh's blessing in war. Inner reflection and self-reflection are needed, even repentance (of course on a social level, not to be confused with individual piety)", ${ }^{36}$

Denise Hopkins and Michael Koppel ${ }^{37}$ refer to the multiplicity in the representation of God and argue that it does not mean that God encompasses only those attributes that support compliant readings or core testimony. While it is important to speak for the tradition and defend God (core testimony), one must always at the same time speak and advocate for fellow human beings (countertestimony). Considering the Shoah (Holocaust), to do theology is "to remember, in pieces, in horrible pieces". ${ }^{38}$ Blumenthal insists that "given Jewish history and family violence as our generations have experienced them, distrust is a proper religious affection, and a theology of sustained suspicion is a proper theology to have". ${ }^{39}$ Readers should learn to accept the reality of God having an abusing as well as a good side and then develop a relationship that offers up their laments, protests, praise or worship, as the situation warrants.

The Hebrew Bible serves for Jews and Christians (along with the New Testament) as performative writings, as a canon, and continue to have practical

35 Scheffler, "War and Violence in the Old Testament World", 10.

36 Scheffler, "War and Violence in the Old Testament World", 11.

37 Denise Hopkins and Michael Koppel, "'Let Them Be Like the Snail that Dissolves into Slime' (Ps. 58:8a): Pastoral and Theological Perspectives on Divine and Human Violence in the Bible," The Journal of Pastoral Theology 23.2 (2013): 212.

38 David R. Blumenthal, Facing the Abusing God: A Theology of Protest (Louisville: WJK, 1993), 9.

39 Blumenthal, Facing the Abusing God, 257. 
value and influence. Both killing for God and being killed (or martyred) for God form the extremes of the commandment not to have other gods than the one true God (Deut 5:7), connecting violence and monotheism. ${ }^{40}$ The result is that texts on violence had (and still can have) catastrophic consequences if they are read as normative.

\section{EARLY PENTECOSTAL HERMENEUTIC AND A VIOLENT GOD}

Edith Blumhofer ${ }^{41}$ argues that their hermeneutic determined Pentecostals' view of themselves as a church awaiting the imminent second coming of Christ, fleeing from denominational Christianity that in their perception became irreparably contaminated when in the fourth century $\mathrm{CE}$, church and state joined forces to establish an earthly kingdom that could never accommodate the reign of God envisioned by Jesus. ${ }^{42}$ By joining Pentecostalism, early participants had separated themselves from the mainstream and when they faced discrimination and persecution from the establishment and its churches they interpreted it eschatologically as a sign of their faithfulness and readiness for the eschaton. ${ }^{43}$ They were now persecuted like the early church because they were citizens of an alternative kingdom with allegiance only to God. They were pilgrims and strangers in this world (Heb 11:13) who refused allegiance to earthly authorities. To participate in war was regarded as incompatible with their citizenry of the kingdom because violence inherent in war was wrong but also because allegiance to God requires one to love the enemy. ${ }^{44}$ Christians should busy themselves with spiritual warfare (2 Cor 10:3-5) in a struggle infinitely more important than any political war between nations (or, more correctly, nation-states). Nationalism was a sin and pride in race and nation was an abomination. ${ }^{45}$

How did they read texts in the Hebrew Bible that depict a God of violence and how did they reconcile that information with their pacifism based on Jesus' injunctions to forgive, turn the other cheek and not to take revenge? For them,

40 Assmann, Die Mosaische Unterscheidung, 48-49; Vimal Tirimanna, "Does Religion Cause Violence?," Studies in Interreligious Dialogue 17.1 (2007): 6.

41 Edith Blumhofer, The Assemblies of God: A Chapter in the Story of American Pentecostalism (Vol. 1: To 1941; Springfield: Gospel Publishing, 1989), 18.

42 Murray W. Dempster, "Pacifism in Pentecostalism: The Case of the Assemblies of God," in The fragmentation of the church and its unity in peacemaking (ed. Jeoffrey Gros and John D. Rempel; Grand Rapids: Eerdmans), 162.

43 Blumhofer, The Assemblies of God, 19.

44 Y.Zink, Turn to Life: The Bible and Peacemaking (trans. V. Rhodin; Philadelphia: Fortress, 1983), 62.

45 Blumhofer, The Assemblies of God, 351; Beaman, Pentecostal Pacifism, 100; Charles H. Mason "Year Book of the Church of God in Christ for the Year 1926." in A Reader in Pentecostal theology: Voices from the First Generation (ed. Douglas Jacobsen; Bloomington: Indiana University Press, 2006), 213-221. 
the Bible served as the inspired Word of God, determining doctrine and lifestyle through the mediation of the Spirit. Scripture had epistemic primacy and merits epistemic priority over, and served as the optimal resource for verifying or falsifying the claims of doctrinal statements. ${ }^{46}$ It must be admitted that when they read the Bible, in most instances they probably did not recognize the historical distance between contemporary believers and the text and did not read the text in terms of its social-cultural and historical setting but as though it was written for their situation. ${ }^{47}$ It was important to read the Bible as literally as possible, ${ }^{48}$ taking it at face value. ${ }^{49}$ In the process, the distance between the original context of Scripture and the context of the reader was collapsed..$^{50}$ They searched the Bible for all Scriptural references to a particular subject and then synthesized those references into a theological statement. It is a harmonizing and deductive method.$^{51}$ And difficult texts were given a new lease of life and applied to the own context by way of allegory, anagogy and typology, ${ }^{52}$ or tracing hidden, spiritual meanings in the text. ${ }^{53}$

What was important for them was not to gain so much information about God from the Bible; what was more essential was to experience an encounter with God in the same terms as described by biblical witnesses ${ }^{54}$ And believers learnt how to verbalize their own experience of encounters with God in order to become a witness to the Pentecostal truth by way of the biblical witnesses. They learnt the vocabulary of their testimonies from the Bible. ${ }^{55}$ To know God was to

46 Craig S. Keener, Spirit Hermeneutics: Reading Scripture in the Light of Pentecost (Grand Rapids: Eerdmans, 2016), 104.

47 Willem J. Wessels, "Skrifgebruik en Samelewing: Die Apostoliese Geloofsending van Suid-Afrika", In die Skriflig 26.3 (1992): 374, referring to the period from 1913 to 1943 in the AFM of SA.

48 Kenneth J. Archer, A Pentecostal Hermeneutic: Spirit, Scripture and Community (Cleveland: CPT, 2009), 65.

49 Archer, Pentecostal Hermeneutic, 66.

50 Lee Roy Martin, "Introduction to Pentecostal Biblical Hermeneutics," in Pentecostal Hermeneutics: A Reader (ed. Lee Roy Martin; Leiden: Brill, 2013), 3; Donald A. Carson, Exegetical Fallacies (Grand Rapids, MI: Baker, 1984), 127.

51 Archer, Pentecostal Hermeneutic, 102.

52 Russell J. Spittler, "Scripture and the Theological Enterprise: A View from the Big Canoe," in The Use of the Bible (ed. Robert K. Johnston; Atlanta: John Knox, 1985), 75-77.

53 John W. McKay, "When the Veil is Taken Away: The Impact of Prophetic Experience on Biblical Interpretation," in Pentecostal Hermeneutics: A Reader (ed. Lee Roy Martin; Leiden: Brill, 2013), 63.

54 Wessels, "Skrifgebruik en Samelewing," 375.

55 Jean-Daniel Pluess, "Azusa and Other Myths: The Long and Winding Road from Experience to Stated Belief and Back Again," Pneuma 15.2 (1993): 191; Scott A. Ellington, "Pentecostalism and the Authority of Scriptures," Journal of Pentecostal Theology 4/9 (1996): 26. 
stand in a relationship with him rather than to have information about him and when you witness about him you talk about your encounter with him in your testimony. ${ }^{56}$ They also understood history in a positivist sense; historical (and scientific) "facts" provided in the Bible are undeniably true because it is contained in the Bible, the Word of God. ${ }^{57}$ That it is written in the Bible guaranteed its truth. They utilized a specific scopus to interpret the Bible, either the Fourfold Full Gospel pre-understanding of Jesus as Saviour, Baptizer, Sanctifier or soon coming King, ${ }^{58}$ or the Fivefold Gospel of Christ as Saviour, Healer, Sanctifier, Baptizer and coming King, that formed the central defining characteristic of the Pentecostal movement. Jesus at the centre of Pentecostal theology was the theological grid that provided a firm interpretive lens for the fluid Pentecostal community and their reading of Scripture. ${ }^{59}$

However, early Pentecostals did not interpret the Bible in a fundamentalist manner ${ }^{60}$ because they did not ascribe authority to the Bible due to its inerrancy or infallibility, but to its utility of showing the way to a personal encounter with God. ${ }^{61}$ This allows them to relegate human violence promoted as God's will to a description of sinful human behaviour that was not viewed as normative for Christians' behaviour. They had been trained to read the Bible by their restorative heritage that gave them the sense that they were the contemporary manifestation of the early church founded in Acts. ${ }^{62}$ And the Pentecostal coming of the Holy Spirit was an empowerment by which they became a radical community of witness to the life, death and resurrection of Jesus and served as the implicit basis for the Pentecostal social ethic that included a strong commitment to pacifism.

56 Ellington, "Pentecostalism and the Authority of Scriptures," i-viii.

57 Daniel E. Albrecht and Evan B. Howard, "Pentecostal Spirituality," in The Cambridge Companion to Pentecostalism (ed. Cecil M. Robeck and Amos Young; New York: Cambridge University Press, 2014), 246-7.

58 William Menzies, "The Methodology of Pentecostal Theology: An Essay on Hermeneutics", in Essays on Apostolic Themes (ed. P. Elbert; Peabody: Hendrickson, 1985), 15; Daniel Tomberlin, Pentecostal Sacraments: Encountering God at the Altar (Cleveland: Center for Pentecostal Leadership and Care, 2010), 35-53.

59 Archer, A Pentecostal Hermeneutic, 137.

60 Paul W. Lewis, "Reflections of a hundred years of Pentecostal theology," Cyberjournal for Pentecostal-Charismatic Research 12 (January 2003), 8. Presented at the $9^{\text {th }}$ Annual William Menzies Lectureship in January, 2001, at Asia Pacific Theological Seminary in Baguio, Philippines, 1-25. http://www.pctii.org/cyberj lcyberj12/lewis.htm\#ftn1.

61 Ellington, "Pentecostalism and the Authority of Scriptures," 17.

62 Wessels, "Skrifgebruik en samelewing", 376. 


\section{LATER PENTECOSTAL HERMENEUTIC AND A VIOLENT GOD}

Early Pentecostalism utilised a hermeneutical angle that allowed them to formulate a pacifist viewpoint to such an extent that most of them did not participate in the First World War, at least not in a combatant capacity. However, in the period before an in the course of the Second World War the movement in general adopted a new hermeneutical stance, leading to abandonment of its pacifist viewpoint. ${ }^{63}$ The second and third generations of Pentecostals in their drive for acceptance by established churches and society closed an alliance with the broader conservative Protestant tradition, cooperating with Evangelicals and resulting in their participation in the establishment of the National Association of Evangelicals (NAE),${ }^{64}$ leading to the "evangelicalisation" of Pentecostals. ${ }^{65}$ Predominantly this happened due to Pentecostals' assimilation into the cultural and religious mainstream and their new social and economic mobility, requiring them to gain acceptance as a denomination and leading to cultural accommodation. In the process they abdicated their theological agenda to Evangelical academic leadership; even Pentecostal Bible schools now employed Evangelical textbooks wholesale and uncritically. ${ }^{66}$ In South Africa, acceptance by Evangelicals did not come easily. ${ }^{67}$

Acceptance by and participation in the Evangelical community, however, came at a cost to Pentecostals. Because they accepted the hermeneutical angle of the Evangelicals with which they formed an alliance, creating a hybrid hermeneutic of their own, ${ }^{68}$ they interpreted the Bible differently in terms of several important issues such as their previous pacifist stance, their permission for women to participate in the ministry, and the involvement of the laity and their democratic participation in worship services and ministry that was sacrificed for the establishment of a professional pastorate in accordance with

63 D. D. Daniels, "North American Pentecostalism" in The Cambridge companion to Pentecostalism, pp. 89-108, (edited by Cecil M. Robeck and Amos Yong, Cambridge University Press, New York, 2014), 97.

64 Robeck, "National Association of Evangelicals," 634-636.; cf. website of NAE, http://nae.net/about-nae/history/.

65 Ellington, "Pentecostalism and the Authority of Scriptures," 151.

66 William W. Menzies and Robert P. Menzies, Spirit and Power: Foundations of Pentecostal Experience (Grand Rapids, MI: Zondervan, 2000), 495.

67 Wessels, "Skrifgebruik en Samelewing", 382. Wessels describes this era in the AFM as the period since 1944.

68 William L. Oliverio, "Introduction: Pentecostal Hermeneutics and the Hermeneutical Tradition," in Constructive Pneumatological Hermeneutics in Pentecostal Christianity (ed. Kenneth J. Archer and L. William Oliverio; New York: Palgrave Macmillan, 2016), 3. 
Evangelical practices. ${ }^{69}$ Most Pentecostals eventually accepted the evangelical viewpoint of the verbal inerrancy and propositional infallibility of Scriptures, aligning themselves to some extent with the fundamentalist use of the Bible, and creating a hybrid between Evangelicalism and fundamentalism, ${ }^{70}$ with a particular pentecostal flavour. ${ }^{71}$ The biblicist-literalist viewpoint consists according to Christian Smith $^{72}$ of mutually interrelated beliefs that state that the Bible in all its details consists of and is identical with God's very own words written inerrantly in human language; that the Bible represents the totality of God's communication to and his will for humanity; that the divine will about all the issues relevant to Christian belief and life is contained in the Bible and applicable to the contemporary situation without fail; that any reasonably intelligent person can read the Bible in his or her own language and correctly understand the plain meaning of the text as its first listeners or readers understood the intended meaning of the author; that all that is needed to interpret the Bible is common sense and the ability to read; that the best way to understand biblical texts is by reading them rigidly in their explicit, plain, most obvious, literal sense, as the author intended it to be read; that the significance of any given biblical text can be understood without reliance on creeds, confessions, historical church traditions, or other forms of larger theological hermeneutical frameworks; that all related passages of the Bible on any given subject fit together almost like puzzle pieces into single, unified, internally consistent bodies of instruction; that what the biblical authors taught God's people at any point in history remains universally valid for all Christians at every other time, unless explicitly revoked by subsequent scriptural teaching; that all matters of Christian belief and practice can be learned by sitting down with the Bible and piecing together through careful study the clear "biblical" truths that it teaches; and that the Bible teaches doctrine and morals with every affirmation that it makes, so that together those affirmations comprise something like a handbook or textbook for Christian belief and living.

When the Bible is interpreted in this manner, it leads to the misuse of biblical texts concerned with justifying violence by selecting a very narrow canon within that canon and making it the whole truth or by allegorising such

69 Mathew Clark, "Contemporary Pentecostal Leadership: The Apostolic Faith Mission of South Africa as Case Study," AJPS 10/1 (2007): 42-61, Online: http://www.apts.edu/aeimages//File/07-_1_Mathew_Clark.pdf

70 William L. Oliverio, Theological Hermeneutics in the Classical Pentecostal Tradition: A Typological Account (Leiden: Brill, 2012), 85.

71 Nancy T. Ammerman, "North-American Protestant fundamentalism," in Media, Culture, and the Religious Right (ed. Linda Kintz and Julia Lesage, 55-113; Minneapolis: University of Minneapolis Press, 1998), 61; Kenneth J. Archer, "Spirited Conversation about Hermeneutics: A Pentecostal Hermeneut's Response to Craig Keener's," Spirit Hermeneutics" Pneuma 39 (2017): 179-1186.

72 Christian Smith, The Bible made impossible: Why Biblicism is not a Truly Evangelical Reading of Scripture (Grand Rapids: Brazos, 2011), 4-5. 
texts and provide a spiritual meaning that explains away the dangerous character of the textual witness. Its supposition is that the Bible does not (and cannot) provide any conflicting views about any issue, and especially not in its representation of God.

It is clear that Pentecostals need a new hermeneutical rationale for reading that can stand its ground when it evaluates the occurrence of the justification of violence in the name of God as found in the Bible, an approach that can honestly face and confront violence in the Bible, from a perspective of faith that leads necessarily to a developed moral conscience. ${ }^{73}$ What is needed is a prophetic spirit that operates from within the faith community, and that lovingly critiques religion and Christians' reading of the Bible from the inside, not with the purpose to destroy it but rather to ensure that the church's moral and ethical viewpoints are good and just.

\section{E A NEW PENTECOSTAL HERMENEUTIC}

Such a new hermeneutic characterises theological developments in the classical Pentecostal movement since the 1970s that allows and even compels the movement to rethink its ethics of a non-pacifist stance. I argue that such a reconsideration has now become imperative to enable Pentecostals to change their ethical stance on and discourse about war and violence, making the church more relevant in a society where most Christians seemingly accept the Augustinian just war doctrine. Pentecostals ought to be faithful embodiments of the story of Pentecost, concludes Joel Shuman, ${ }^{74}$ because it is their distinctive testimony that at Pentecost God made possible the existence of a community whose willingness to live "filled with the Spirit" makes present to the world the reality of God's kingdom consisting of an alternative polis of peaceful coexistence. A reality centred around such a peacekeeping vision certainly precludes any level of participation in killing.

As far as the Bible is concerned, Pentecostals need to address several issues if they wish to recover their heritage of pacifism. Especially the Hebrew Bible poses challenges because of its many portrayals of YHWH as a violent God. In the first place, Pentecostals should note the negative effects of a fundamentalist view of the Bible as the "word of God" that implies that the Bible contains a unified and monolithic view on war and violence (or other issues). ${ }^{75}$

73 Flood, Disarming Scripture, 26.

74 Joel Shuman, "Pentecost and the End of Patriotism: A Call for the Restoration of Pacifism among Pentecostal Christians,"” Journal for Pentecostal Theology 9 (1996): 96.

75 Jonathan Sacks, Not in God's Name: Confronting Religious Violence (New York: Schocken, 2015), 207; Bradley Truman Noel, Pentecostal and Postmodern Hermeneutics: Comparisons and Contemporary Impact (Eugene, OR: WIPF \& STOCK, 2010), 13, 74. 
The net result of patiently comparing the different traditions found in the Bible indicates and demonstrates that the Bible does not speak in a monosyllabic way. ${ }^{76}$ It should be emphasised that the Hebrew Bible contains conflicting views on violence that cannot be systematised into a clearly uniform "biblical view" on violence that could function as a prescriptive norm for Christians today. "The Bible should be exegeted according to its true nature: various books that contain a kaleidoscopic diversity of different and even contrary views on war and violence that dialogue with one another. Such an approach would facilitate tolerance". ${ }^{77}$ Scheffler also observes that the Bible should be studied in its Weltbezogenheit, that is, the reality of mundane life with all its complexities including individual feelings of love, hatred and physical, social and material needs that determine how people and groups react. It should be kept in mind that the views encountered in the Hebrew Bible are the product of historical circumstances in which the texts originated and that it correlated with the needs of a specific community at a specific stage in history. The issue of war and violence should be fully recognised as part of the condition humana, especially in the sense of its predicament. The human dynamic and psychology behind texts that discuss war and violence should be understood to ensure that the texts do not serve mindlessly as normative for conflicts found in the modern day.

All forms of glorification of violence in the national dialogue, including parents' telling of war stories or in education departments' curricula of their country's history should be rooted out. History should be presented to children and other citizens in all its gory cruelty and children should be made aware of the dangers lurking in politicians' abuse of power. Instead of describing war in terms of politics or heroism it should be presented as the mass murder machine that it is.

Pentecostals' tendency to read the Bible in a historicist sense, in other words, as though it were written for their own day and circumstances, should be exposed for what it is, as a potentially dangerous hermeneutic that could cause them to become embroiled in inhumane behaviour.

The language of war in the Hebrew Bible and other ancient Near Eastern literatures is acutely masculinist and the discourse of violence is closely imbricated with that of masculine sexuality defined by prowess in battle and the ability to sire children. ${ }^{78}$ Manhood entails the capacity to exert violence; "man" and "woman" are mobile constructs, a complementary pair of signifiers

76 Harvey Cox, How to read the Bible (New York: HarperCollins, 2015), 177.

77 Scheffler, "War and Violence in the Old Testament World," 15.

78 Harry A. Hoffner, "Symbols for Masculinity and Femininity: Their Use in Ancient Near Eastern Sympathetic Magic Rituals," Journal of Biblical Literature 85.3(1966):327. 
reciprocally determined by their relation to violence. ${ }^{79}$ The biblical representation of sexual violence, too, demonstrates that violence against a feminine object is elemental to normative masculinity. In this sense, gender becomes a crucial articulator of the experience of violence and gendered discourse becomes a means of producing relations of violence and domination, authenticating a violent male prerogative that remains culturally potent into the present where the Bible is read, believed and applied in a historicist sense. The result is, for instance, that the deuteronomistic war laws are regarded as salutary attempts to curb violence or to protect people from its effects, rendering intelligible and acceptable both warfare (20:1-20), an institutionalised form of rape (21:10-14) and valorising violent acts, construing them as essential to male agency. ${ }^{80}$ It bases male subjectivity in violent relation to a female object and creates a field of power where social relations based on a violent masculine prerogative are inevitable. And as foundational texts of Western culture, these "biblical" laws authenticate the role of violence in the cultural construction of gender up to the present day, demonstrating the danger in reading the Bible in this way. Rape and rapability are central to the very construction of gender identity ${ }^{81}$ And it can be argued that the prevalence of rape in biblical narrative suggests that ancient Israel should be designated a rape culture. ${ }^{82}$

\section{F SYNTHESIS}

It was argued that most early Pentecostals supported pacifism because of their literal obedience to Jesus' ethical injunctions to love one's enemies and turn the

79 H. C. Washington, "Violence and the Construction of Gender in the Hebrew Bible: A New Historicist Approach," Biblical Interpretation 5.4 (1997): 331.

80 Washington, "Violence and the Construction", 344.

81 Lynn A. Higgins and Brenda A. Silver, "Introduction: Rereading Rape," in Rape and Representation (ed. Lynn A. Higgins and Brenda A. Silver; New York: Columbia University Press, 1991), 2. (Gender and Culture).

82 Cf. Hagar (Gen 16:3-4), Dinah (Gen 34:2), the Midianite young women (Num 31:18), the Levite's wife (Judg 19:25), the young women of Jabesh-Gilead and Shiloh (Judg 21:12-14, 19-23), Rizpah (2 Sam 3:7), Bathsheba (2 Sam 11:2-4), Tamar (2 Sam 13:11-15), and David's wives (2 Sam 16:21-22) where sexual assault and coercion are considered commonplace, demonstrating the so-called "rape laws" of Deuteronomy 22:23-29. These laws do not in fact prohibit rape; they institutionalise it and confirm men's control of women. Rather than "rape laws", the rules of Deuteronomy 22:23-29 are best classified as a subset of the general law of adultery preceding them in Deuteronomy 22:22. The Deuteronomist laws clearly intend to protect a patriarchal household against the theft of a marriageable woman without the paying of a bride price. It does not prohibit sexual violence but rather stipulates the terms under which a man may commit rape, provided he pays reparation to the offended male party. Rape is also a prominent figurative device in the Hebrew Bible, especially in the metaphorical depiction of the conquered city as a raped woman and of the punishing God as a vengeful rapist. One instance is Jeremiah 13:20-27 that envisions the Babylonian attack on Jerusalem as a divine rape (Washington, "Violence and the Construction", 354-355). 
other cheek. The Pentecostal moral commitment to pacifism should be appreciated against this restorationist understanding of church history. Certain events and developments since the 1930s triggered a basic shift in Pentecostal belief about Christians bearing arms and participating in battles against the background of worldwide stigmatisation and criminalisation of any peace-talk by governments. In its quest to shed its image as a looked for acceptance and approval by the state and community. They allied with Evangelicals and accepted their fundamentalist hermeneutic and patriotism. Pacifism was left out of the Pentecostals' agenda. Since the 1970s, a new Pentecostal hermeneutical consensus among scholars have viewed the coming of the Holy Spirit as an empowerment by which the Christian community served as the implicit basis for the Pentecostal social ethic that included a strong commitment to pacifism.

\section{BIBLIOGRAPHY}

Albrecht, Daniel E. and Evan B. Howard. "Pentecostal Spirituality." Pages 246-7 in The Cambridge Companion to Pentecostalism. Edited by Cecil M. Robeck and Amos Young, New York: Cambridge University Press, 2014. https://doi.org/10.1017/CCO 9780511910111.017

Ammerman, Nancy T. "North-American Protestant fundamentalism." Pages 55-113 in Media, Culture, and the Religious Right. Edited by Linda Kintz and Julia Lesage, Minneapolis: University of Minneapolis Press, 1998.

Archer, Kenneth J. A Pentecostal Hermeneutic: Spirit, Scripture and Community. Cleveland: CPT, 2009.

Archer, Kenneth J. "Spirited Conversation about Hermeneutics: A Pentecostal Hermeneut's Response to Craig Keener's Spirit Hermeneutics." Pneuma 39 (2017): 179-197. https://doi.org/10.1163/15700747-03901007

Armstrong, Karen. Fields of Blood: Religion and the History of Violence. London: The Bodley Head, 2014.

Assmann, Jan. Die Mosaische Unterscheidung oder der Preis des Monotheismus. München: Hanser, 2013.

Beaman, Jay. Pentecostal Pacifism: The Origins, Development and Rejection of Pacifist Beliefs among the Pentecostals. Hillsboro: Center for Mennonite Brethren Studies, 1989.

Beaman, Jay. "Pentecostal and holiness pacifism." Pentecostal pacifism 2009, 1-3.

Beaman, Jay. "Introduction." Page 43 in Pentecostal and Holiness Statements on War and Peace. Edited by Jay Beaman \& Brian K. Pipkin, Eugene, Or.: Pickwick, 2013.

Blumenthal, David R. Facing the Abusing God: A Theology of Protest. Louisville: WJK, 1993.

Blumhofer, Edith L. The Assemblies of God: A Chapter in the Story of American Pentecostalism. Vol. 1: To 1941, Springfield: Gospel Publishing, 1989.

Cabal, Ted et al., The Apologetics Study Bible: Real Questions, Straight Answers, Stronger Faith. Nashville: Holman Bible Publishers, 2007.

Carson, Donald A. Exegetical Fallacies. Grand Rapids, MI: Baker, 1984. 
Clark, Mathew. "Contemporary Pentecostal Leadership: The Apostolic Faith Mission of South Africa as Case Study." Asian Journal of Pentecostal Studies 10/1 (2007): 42-61. Online: http://www.apts.edu/aeimages//File/07-_1_Mathew_Clark.pdf

Collins, John J. "The Zeal of Phinehas: The Bible and the Legitimation of Violence." Journal of Biblical Literature 122.1(2003):14.

Collins, John J. Does the Bible Justify Violence? Minneapolis: Fortress, 2004.

Cox, Harvey. How to read the Bible. New York: HarperCollins, 2015.

Daniels, D. D. "North American Pentecostalism." Pages 73-92 in The Cambridge companion to Pentecostalism. Edited by Cecil M. Robeck and Amos Yong, Cambridge University Press, New York, 2014. https://doi.org/10.1017/CCO9780511910111.008

Dawkins, Richard. The God Delusion. New York: Houghton Mifflin Harcourt, 2006.

Dempster, Murray W. "Pacifism in Pentecostalism: The Case of the Assemblies of God." Pages 137-65 in The Fragmentation of the Church and its unity in peacemaking. Edited by Jeoffrey Gros and John D. Rempel, Grand Rapids: Eerdmans.

Ellington, Scott A. "Pentecostalism and the Authority of Scriptures". Journal of $\begin{array}{llll}\text { Pentecostal Theology } & \text { 4/9 (1996): }\end{array}$ https://doi.org/10.1177/096673699600400902

Flood, Derek. Disarming Scripture: Cherry-Picking Liberals, Violence-Loving Conservatives, and why we all need to Learn to Read the Bible Like Jesus Did. San Francisco: Metanoia, 2014.

Gutiérrez, Gustavo. The Truth Shall Make you Free: Confrontations. Translated by M. J. O’ Connell. Maryknoll, NY: Orbis, 1990.

Hauerwas, Stanley. After Christendom: How the Church is to behave if Freedom, Justice, and a Christian Nation are Bad Ideas. Nashville: Abingdon, 1991.

Hauerwas, Stanley. "Sacrificing the Sacrifices of War." Criswell Theological Review 4.2(2007):80.

Higgins, Lynn A. and Brenda A. Silver, "Introduction: Rereading Rape." Pages 1-11 in Rape and Representation. Edited by Lynn A. Higgins and Brenda A. Silver, New York: Columbia University Press, 1991.

Hoffner, Harry A. "Symbols for Masculinity and Femininity: Their Use in Ancient Near Eastern Sympathetic Magic Rituals." Journal of Biblical Literature 85.3(1966):327.

Hopkins, Denise D. and Michael S. Koppel. "Let Them Be Like the Snail that Dissolves into Slime' (Ps. 58:8a): Pastoral and Theological Perspectives on Divine and Human Violence in the Bible." The Journal of Pastoral Theology 23.2(2013):212.

Keener, Craig S. Spirit Hermeneutics: Reading Scripture in the Light of Pentecost. Grand Rapids: Eerdmans, 2016.

Lewis, Paul W. "Reflections of a hundred years of Pentecostal theology." Cyberjournal for Pentecostal-Charismatic Research 12 (January 2003),1-10.

Lind, Millard C. Yahweh is a Warrior. Scottdale: Herald, 1980.

Martin, Lee Roy. "Introduction to Pentecostal Biblical Hermeneutics." Pages 1-9 in Pentecostal Hermeneutics: A Reader. Edited by Lee Roy Martin. Leiden: Brill, 2013.

Mason, Charles H. "Year Book of the Church of God in Christ for the Year 1926." Pages 213-221 in A Reader in Pentecostal theology: Voices from the First 
440 Nel, “Pentecostal Pacifist Impulse,” 31/2 (2018): 423-441

Generation. Edited by Douglas Jacobsen, Bloomington: Indiana University Press, 2006.

McKay, John W. "When the Veil is Taken Away: The Impact of Prophetic Experience on Biblical Interpretation." Pages 57-80 in Pentecostal Hermeneutics: A Reader. Edited by Lee Roy Martin, Leiden: Brill, 2013. https://doi.org/10.1163/9789004258259_006

Menzies, William. "The Methodology of Pentecostal Theology: An Essay on Hermeneutics." Pages 35-53 in Essays on Apostolic Themes. Edited by P. Elbert, Peabody: Hendrickson, 1985.

Menzies, William W. and Robert P. Menzies. Spirit and Power: Foundations of Pentecostal Experience. Grand Rapids, MI: Zondervan, 2000.

Noel, Bradley Truman. Pentecostal and Postmodern Hermeneutics: Comparisons and Contemporary Impact. Eugene: WIPF \& STOCK, 2010.

Oliverio, William L. "Introduction: Pentecostal Hermeneutics and the Hermeneutical Tradition." Pages 1-14 in Constructive Pneumatological Hermeneutics in Pentecostal Christianity. Edited by Kenneth J. Archer and L. William Oliverio, New York: Palgrave Macmillan, 2016.

. Theological Hermeneutics in the Classical Pentecostal Tradition: A Typological Account. Leiden: Brill, 2012.

Pluess, Jean-Daniel. "Azusa and Other Myths: The Long and Winding Road from Experience to Stated Belief and Back Again." Pneuma 15.2(1993):191.

Pluess, Jean-Daniel. "Pentecostalism in Europe and the Former Soviet Union." Pages 93-111 in The Cambridge Companion to Pentecostalism. Edited by Cecil M. Robeck \& Amos Yong, New York: Cambridge University Press, 2014. https://doi.org/10.1017/ CCO9780511910111.009

Reid, Daniel G. and Tremper Longman. "When God Declares War: The Violence of God can only be understood in the Shadow of the Cross." Christianity Today (October 28, 1996): 17.

Robeck, Cecil M. "National Association of Evangelicals." Pages 634-6 in Dictionary of Pentecostal and charismatic movements. Edited by S.M. Burgess \& G.B. McGee, Zondervan, Grand Rapids, 1988.

Rowlett, Lori. Joshua and the Rhetoric of Violence: A New Historical Analysis. Sheffield: Sheffield Academic Press, 1996.

Sacks, Jonathan. Not in God's Name: Confronting Religious Violence. New York: Schocken, 2015.

Scheffler, Eben. "War and Violence in the Old Testament World: Various Views." Pages 1-17 in Animosity, the Bible, and us. Edited by John T. Fitzgerald, Fika J. Van Rensburg and Herrie F. Van Rooy. Atlanta: SBL, 2009.

Schwager, Raymund. Must there be Scapegoats? Violence and Redemption in the Bible. Translated by M.L. Assad. San Francisco: Harper \& Row, 1987.

Schwally, Friedrich. Der Heilige Krieg im Alten Israel. Leipzig: Dieterich'sche Verlagsbuchhandlung, 1910.

Shadle, Mathew. "Theology and the Origins of Conflict: The Shining Path Insurgency in Peru, 1980-2000." Political Theology 14.3(2013):302. DOI 10.1179/1462317X13Z.0000000.

Sharp, Carolyn J. “'Are You for Us, Or for our Adversaries?' A Feminist and Postcolonial Interrogation of Joshua 2-12 for the Contemporary Church." Interpretation: A Journal of Bible and Theology 66/2 (2012):152. 
Shuman, Joel. "Pentecost and the End of Patriotism: A Call for the Restoration of Pacifism among Pentecostal Christians." Journal for Pentecostal Theology 9 (1996): 70- 96. https://doi.org/10.1177/096673699600400905

Sider, Ron J. and R. K. Taylor. "Jesus and Violence: Some Critical Objections." Pages 505-15 in Readings in Christian Ethics. Edited by David K. Clarke and Robert V. Rakestraw. Vol. 2: Issues and application. Grand Rapids: Baker Academic, 1996.

Smith, Christian. The Bible made impossible: Why Biblicism is not a Truly Evangelical Reading of Scripture. Grand Rapids: Brazos, 2011.

Spittler, Russell J. "Scripture and the Theological Enterprise: A View from the Big Canoe." Pages 75-7 in The Use of the Bible. Edited by Robert K. Johnston, Atlanta: John Knox, 1985.

Tomberlin, Daniel. Pentecostal Sacraments: Encountering God at the Altar. Cleveland: Center for Pentecostal Leadership and Care, 2010.

Vestdijk, Simon. De toekomst der religie. Arnhem: Van Loghum Slaterus, 1952.

Von Rad, Gerhard. Der Heilige Krieg im Alten Israel. Göttingen: Vandenhoeck \& Ruprecht, 1951.

Walvoord, John F. and Roy B. Zuck. The Bible Knowledge Commentary: Old Testament. Colorado Springs: David C. Cook, 1984.

Washington, H. C. "Violence and the Construction of Gender in the Hebrew Bible: A New Historicist Approach.” Biblical Interpretation 5/4 (1997): 324-364. https://doi.org/10. 1163/156851597X00120

Wessels, Wilhelm J. "Skrifgebruik en samelewing: Die Apostoliese Geloofsending van Suid-Afrika." In die Skriflig $26.3 \quad$ (1992): $369-84$. https://doi.org/10.4102/ids.v26i3.1422

Zehnder, Markus. "The annihilation of the Canaanites: Reassessing the brutality of the biblical witnesses." Pages 263-90 in Encountering violence in the Bible. Edited by Markus Zehnder and Hallvard Hagelia, Sheffield: Sheffield Phoenix, 2013.

Zink, Y. Turn to Life: The Bible and Peacemaking. Translated by V. Rhodin. Philadelphia: Fortress, 1983.

Marius Nel, Research Chair, Ecumenism: Pentecostalism and neopentecostalism, Unit for Reformed Theology, North-West University. PO Box 19659, Noordbrug. 2522; 015 299-1591; 083 454-9126; marius.nel@nwu.ac.za. ORCID ID: https://orcid.org/0000-0003-0304-580. 